\title{
Patience and Precipitation: Two Figures of Historical Change
}

\section{Enlightenment as Infection}

The following deliberations on the temporality of historical change begin with a short passage from Georg Wilhelm Friedrich Hegel's Phenomenology of Spirit titled "The Struggle of the Enlightenment with Superstition" ("Der Kampf der Aufklärung mit dem Aberglauben"). In considering this struggle primarily in formal or technical terms, they might at first seem to contradict the intentions of Hegelian philosophy, which is explicitly concerned with the "guises of spirit" ("Gestalten des Geistes"), not those of techniques or technology [Technik]. ${ }^{1}$ But even if Hegel's overall topic is "spirit," when it comes to the details he is an extraordinarily precise and knowledgeable observer of the physical, material, and technical processes in and through which the "movement of the concept" ("Bewegung des Begriffs") is accomplished. ${ }^{2}$ In his depiction of the struggle between Enlightenment and superstition, his interest in cultural techniques is even at the forefront: what fascinates Hegel about the Enlightenment is not at all its ideology; it is its artifices, the procedures and dynamics of its implementation. For Hegel, the famous question "What is Enlightenment?" is replaced by the question of how Enlightenment functions: how could the Enlightenment assert itself - so thoroughly and seamlessly that, around 1800 , it became possible to speak generally of a "triumph of philosophy" or a "victory of Enlightenment"?

To clarify this question, Hegel offers two models that initially seem to contradict each other, but which ultimately - and this is the dialectic - are shown to complement each other and play into each other's hands. These models are based on two different figures of temporality. Hegel himself does not name them; in order to differentiate them more easily, here they will be called "patience" and

1 Georg Wilhelm Friedrich Hegel, "Hegels Selbstanzeige (Intelligenzblatt der Jenaer Allgemeinen Literatur-Zeitung, 28. Oktober 1807),” in G.W.F.H., Phänomenologie des Geistes: Werke, vol. 3, ed. Eva Moldenhauer and Karl Markus Michel (Frankfurt am Main: Suhrkamp, 1986), 593; translated by Terry Pinkard as "Hegel's Advertisement and Hegel's Note to Himself," in Hegel, The Phenomenology of Spirit (Cambridge: Cambridge University Press, 2018), 468 (translation modified).

2 See Hegel, Phänomenologie, 38; Phenomenology, 22.

Translated by Michael Thomas Taylor

Ә Open Access. (C) 2020 Stephan Gregory, published by De Gruyter. (ब)BY This work is licensed under a Creative Commons Attribution 4.0 International License.

https://doi.org/10.1515/9783110647044-016 
"precipitation." The efficacy of these two figures is not limited to the historical context of the Enlightenment; rather, they represent two fundamental forms of the effect of time in history. As such, "patience" and "precipitation" not only stand for different interpretations of historical change. They can also be regarded as temporal logics that operate in historical events themselves. First, the figure of “patience.” Hegel describes it thus:

Die Mitteilung der reinen Einsicht ist deswegen einer ruhigen Ausdehnung oder dem Verbreiten wie eines Duftes in der widerstandslosen Atmosphäre zu vergleichen. Sie ist eine durchdringende Ansteckung, welche sich nicht vorher gegen das gleichgültige Element, in das sie sich insinuiert, als Entgegengesetztes bemerkbar macht und daher nicht abgewehrt werden kann. Erst wenn die Ansteckung sich verbreitet hat, ist sie für das Bewußtsein, das sich ihr unbesorgt überließ. ... Sowie daher die reine Einsicht für das Bewußtsein ist, hat sie sich schon verbreitet; der Kampf gegen sie verrät die geschehene Ansteckung; er ist zu spät, und jedes Mittel verschlimmert nur die Krankheit, denn sie hat das Mark des geistigen Lebens ergriffen ... [N] un ein unsichtbarer und unbemerkter Geist, durchschleicht sie die edlen Teile durch und durch und hat sich bald aller Eingeweide und Glieder des bewußtlosen Götzen gründlich bemächtigt, und 'an einem schönen Morgen gibt sie mit dem Ellbogen dem Kameraden einen Schub, und Bautz! Baradautz! der Götze liegt am Boden' ...

For that reason, the communication of pure insight is comparable to a peaceful diffusion of something like a scent in a compliant atmosphere. It is a pervading infection and is not noticeable beforehand as being opposed to the indifferent element into which it insinuates itself; it thus cannot be warded off. It is only when the infection has become widespread that it is for consciousness. ... As soon as pure insight thus is for consciousness, this insight has already made itself widespread, and the struggle against it betrays the fact that the infection has already taken hold. The struggle is too late, and all the remedies taken only make the disease worse, for the disease has seized the very marrow of spiritual life ... [N]ow that it is an invisible and undetected spirit, it winds its way all through the nobler parts, and it has soon taken complete hold over all the fibers and members of the unaware idol. At that point, "some fine morning it gives its comrade a shove with the elbow, and, thump! kadump! the idol is lying on the floor"...

What is Hegel talking about? First of all, we can name the two opponents facing each other in this contest: on the one hand, the form of consciousness of faith, i.e., the traditional Christian world view; and on the other, "pure insight," i.e., the figure of a "pure," self-grounding reason that recognizes no authority but its own ${ }^{4}$ - in other words, what we could for the sake of simplification call "modern," "Cartesian"

3 Hegel, Phänomenologie, 402f.; Phenomenology, 316f.

4 See Hegel, Phänomenologie, 398: "Diese reine Einsicht ist also der Geist, der allem Bewußtsein zuruft: seid für euch selbst, was ihr alle an euch selbst seid, - vernünftig.” Phenomenology, 313: "This pure insight is thus the spirit that calls out to every consciousness: Be for yourselves what you all are in yourselves - rational." 
rationality. ${ }^{5}$ The one party (faith) is overcome by the other (pure insight), and this happens in a way that Hegel finds remarkable, or at least more remarkable than what pure insight itself has to say. Hegel is primarily interested here in the process by which pure insight displaces the system of faith; and he is obviously pleased by the metaphor he has found for it: if pure insight is a disease afflicting faith, the Enlightenment represents nothing but the process of infection through which it spreads. ${ }^{6}$ In other words, Enlightenment does not represent a substantial corpus of knowledge, nor does it stand for a particular figure of consciousness (this is rather what "pure insight" does). It primarily denotes a form of dissemination - a specific, highly effective form of "impartion" (Mitteilung); or, to put it bluntly, a "communication strategy." Despite all the reluctance that Hegel is compelled to express against such low-content packaging and marketing expertise, this is still what interests him in the venture of Enlightenment: what is decisive is not what the Enlightenment wants (for Hegel, this seems completely banal and not the least bit removed from old prejudices); rather, it is that the Enlightenment seems to have found a new formula for history: a procedure for the production of historical changes, as noiseless as it is effective, which Hegel understands and describes as "infection."

The choice of words itself is not particularly original. Since the idea of infection was first conceived, there has also been a lively metaphorical intercourse between forms of disease transmission and socially operative processes of transmission. The plague never designates just a physical illness; it also always stands for the disintegration of social ties. René Girard, who examined the plague metaphor in the context of his theory of mimetic desire, quotes a famous sixteenth-century doctor, the surgeon Ambroise Paré:

As soon as the plague becomes evident, it is not unlikely that even the highest authorities will flee ... General anarchy and confusion take hold, and there can be nothing worse for the community, because this is the moment when disorder brings about a plague of a different kind, a plague that is much worse. ${ }^{7}$

The idea of labeling the opposing position as infectious - and thus as particularly insidious - is not new, either. Particularly in the debates about Enlightenment,

5 See Michael Pfister, "Aufklärung als Ansteckung: Zu einer Passage in Hegels 'Phänomenologie des Geistes,"” in Ansteckung: Zur Körperlichkeit eines ästhetischen Prinzips, ed. Mirjam Schaub, Nicola Suthor, and Erika Fischer-Lichte (Munich: Fink, 2005), 263-274, here 264.

6 Hegel confirms this differentiation; he speaks "of pure insight and of its diffusion, the Enlightenment" (Phenomenology, 314); "von der reinen Einsicht, und ihrer Verbreitung, der Aufklärung” (Phänomenologie, 400).

7 René Girard, “Die Pest in Literatur und Mythos,” in R.G., Die verkannte Stimme des Realen: Eine Theorie archaischer und moderner Mythen (Munich: Hanser, 2005), 153-154. 
a constant ping-pong of such accusations and counteraccusations plays out. For instance, the proponent of French materialism Paul Thiry d'Holbach speaks in 1768 of a "Contagion sacrée," superstition obstinately survives; conversely, the propagandists of the counterenlightenment never tire of hurling epidemiological metaphors at their enemies: these critics speak of insidious poisons that undermine the health of the community, of invisible worms that attack the body of the state and eventually cause its demise.

What distinguishes Hegel's portrayal of the Enlightenment as infection from the polemics of counter-enlightenment is not only the moment of fascination it contains. It is also the analytical precision with which he operates. Hegel does not simply use the metaphor of infection; he analyzes it. What is so captivating about the image of infection? What makes it interesting for use as a political metaphor? Hegel's depiction is focused on two obviously interrelated motifs: first, that of the invisibility of the opponent; and second, that of its particular chronological sequence.

As Hegel shows, religion's confrontation with the Enlightenment must lead to religion's downfall precisely because this conflict cannot be recognized as a confrontation. There is no front, no clear boundary, separating one party from the other, for it is part of the unspoken strategy of Enlightenment to not meet the old system with maximum contradiction, but with a multitude of small advances that do not by themselves provoke resistance. Faith is imperceptibly infected, as it were, by pure insight. Without any compulsion to do so, faith begins to defend its convictions with precisely the same rational means that Enlightenment used against faith. In this way, being drawn onto the field of its opponent, "religion accepts in advance the logic of its enemy." 9 An example of this maneuver is the way faith responds to the arguments of rational Biblical criticism. True faith needs no confirmation; source-critical studies of the historical significance of Holy Scriptures are completely alien to faith.

In der Tat aber fällt es dem Glauben nicht ein, an solche Zeugnisse und Zufälligkeiten seine Gewißheit zu knüpfen; er ist in seiner Gewißheit unbefangenes Verhältnis zu seinem absoluten Gegenstande, ein reines Wissen desselben, welches nicht Buchstaben, Papier und Abschreiber in sein Bewußtsein des absoluten Wesens einmischt und nicht durch solcherlei Dinge sich damit vermittelt. ${ }^{10}$

8 See Pfister, “Aufklärung als Ansteckung,” 265.

9 Slavoj Žižek, For They Know Not What They Do: Enjoyment as a Political Factor (New York: Verso, 2008 [1991]), 65.

10 Hegel, Phänomenologie, 410-411; Phenomenology, 322-323. 
But in fact it never even occurs to faith to link its certainty to that kind of testimony and those kinds of contingencies. In its certainty, faith stands in an unencumbered relation to its absolute object. It is a pure knowing of that object, and it never lets letters, paper, or copyists interfere with its consciousness of the absolute essence; it does not mediate itself with the absolute essence by those kinds of things.

But it is difficult for faith to evade the burden of proof. Faith becomes increasingly involved in the debates of rational theology, itself becoming interested in the contingencies of written tradition, in the role that "letters, paper, and copyists" play in constituting the truth of faith. Faith thus already finds itself on the field of its opponent, has subjected itself to its opponent's method of argumentation, has already lost:

Wenn der Glaube sich aus dem Geschichtlichen auch jene Weise von Begründung ... geben will und ernsthaft meint und tut, als ob es darauf ankäme, so hat er sich schon von der Aufklärung verführen lassen; und seine Bemühungen, sich auf solche Weise zu begründen oder zu befestigen, sind nur Zeugnisse, die er von seiner Ansteckung gibt. ${ }^{11}$

However much faith wishes to substantiate itself ... and if it wishes to do this by drawing on what is historical, and if furthermore it seriously thinks and acts as if something really depended on its doing so, then so has it already let itself be seduced by the Enlightenment. Its efforts to ground itself or to bolster itself in this way only amounts to testimony that attests to its infection by the Enlightenment.

The quotation Hegel has woven into the text also speaks of the unsurpassable effectiveness of an antagonism that does not reveal itself as such. The passage, namely, is taken from Denis Diderot's dialogue Rameau's Nephew, which was published for the first time in 1805 in German, in Goethe's translation. Here the strategy of imperceptible land seizure - a common topos of Enlightenment - is traced back to Jesuit missionary practices:

Dieser fremde Gott setzt sich bescheiden auf den Altar, an die Seite des Landesgötzen. Nach und nach gewinnt er Platz, und an einem hübschen Morgen giebt er mit dem Ellbogen seinem Kameraden einen Schub und Bautz! Baradautz! der Götze liegt am Boden. So sollen die Jesuiten das Christenthum in China und Indien gepflanzt haben, und eure Jansenisten mögen sagen, was sie wollen, diese politische Methode, die zum Zweck führt, ohne Lerm, ohne Blutvergießen, ohne Märtyrer, ohne einen ausgerauften Schopf, dünkt mich die beste. ${ }^{12}$

11 Hegel, Phänomenologie, 411; Phenomenology, 323.

12 Denis Diderot, Rameaus Neffe: Ein Dialog, trans. Johann Wolfgang von Goethe (Leipzig: Göschen, 1805), 282-283; Rameau's Nephew and D'Alembert's Dream, trans. Leonard Tancock (New York: Penguin, 1966), 101. 
The foreign god takes his place unobtrusively beside the idol of the country, but little by little he strengthens his position, and one find day he gives his comrade a shove with his elbow and wallop! down goes the idol. That, they say, is how the Jesuits planted Christianity in China and the Indies. And the Jansenists can say what they like, this kind of politics which moves noiselessly, bloodlessly towards its goal, with no martyrs and not a single tuft of hair pulled out, seems the best to me.

The intertwining of the temporal figures, which Hegel subsequently develops in more detail, distinctively emerges here: first, the gradual erosion of the opposing position, a strategy of waiting, which can be described with the term "patience"; and then the little shove that - wallop! - brings the position crashing down: a minimal gesture that does not require much effort but nevertheless stands out from among the series of inconspicuous, modest acts that seize space step by step. Insofar as this second movement requires a decision that is not contained in the logic of waiting, we can try to grasp it with the concept of "precipitation." Following Slavoj Žižek, the "double scansion" characterizing the dialectic process as a whole can be found in this joint between two forms of time:

First, we have the "silent weaving of the Spirit," the unconscious transformation of the entire symbolic network, the entire field of meaning. Then, when the work is already done and when "in itself" all is already decided, it is time for a purely formal act by means of which the previous shape of Spirit breaks up also "for itself." ... The strategy of the New, of the spiritual "illness," must therefore be to avoid direct confrontation for as long as possible; a patient "silent weaving," like the underground tunneling of a mole, waiting for the moment when a light push with the finger will be enough for the mighty edifice to fall to pieces. ${ }^{13}$

As Diderot's example shows, Hegel could have developed the connection between the two forms of time even without an epidemiological reference (Diderot speaks of Christianity being "planted," but this does not necessarily imply the idea of spreading like the plague). When Hegel invokes the metaphor of infection, which is unusual in the context of a philosophy of consciousness, he obviously does so because the natural and social events he describes seem themselves to have a certain logic, that is, in a certain sense, they have the shape of Spirit.

\section{Plague and Time}

In order to understand how this metaphor of infection functions, it is first necessary to clarify what "infection" was capable of meaning for Hegel, that is, in the

13 Žižek, For They Know Not What They Do, 65. 
period around 1800. In particular, it seems, we must beware of the temptation of retrodiagnosis, i.e., of a reading that projects today's medical knowledge onto historical descriptions of diseases. For example, Hegel obviously alludes in the passage quoted above to the plague's mode of infection, but as the word "miasma" (Pesthauch) that Hegel uses shows, the plague that Hegel has in mind cannot be the same disease we speak of today. It is not even necessary here to investigate the pedantic question of whether the pathogen that causes the plague, Yersinia pestis, existed before it was discovered by Alexandre Yersin in $1894^{14}$; here, it is sufficient to note that "plague" is a term that has been applied to all kinds of epidemics throughout history and that, even in the period around 1800, its meaning was by no means clearly fixed to a particular clinical picture.

Contagio has been an established term in medical discourse since Alessandro Benedetti's De observatione in pestilentia of 1493. In his 1546 treatise De contagione et contagiosis morbis et eorum curatione, Girolamo Fracastoro distinguishes between three different modes of transmission: an infection based on direct contact ("contactu"), one transmitted by objects such as household effects and clothing ("fomite"), and one that also works at a distance ("ad distans"). ${ }^{15}$ In 1658 , Athanasius Kircher contributed the hypothesis that the plague was caused by tiny worms ("vermiculi") "not perceptible to the unaided eye," 16 which accumulated in the blood of the sick and spread through contact ("per contactum") or through the vapors discharged by the corpses ("effluvia"). In addition, in the hospitalization and quarantine practices of late-medieval cities, a practical knowledge of infection was developed early on to which "scientific medicine ... [reacted] in part only after centuries of 'delay.', 17

Unfazed by the knowledge of transmission established in this way, however, the old miasma theory of the plague connected with ancient theories of humoralism persisted into the nineteenth century, that is, the idea that a concentration of "bad air" or "evil vapors" was responsible for the outbreak of the disease.

In a book published in 1968, the French philosophical historian Jacques D'Hondt set out to find the "hidden sources of Hegelian thought." D'Hondt

14 Bruno Latour, "Haben auch Objekte eine Geschichte? Ein Zusammentreffen von Pasteur und Whitehead in einem Milchsäurebad,” in B.L., Der Berliner Schlüssel: Erkundungen eines Liebhabers der Wissenschaften (Berlin: Akademie-Verlag, 1996), 87-112.

15 Girolamo Fracastoro, De Sympathia Et Antipathia Rerum Liber Unus: De Contagione Et Contagiosis Morbis Et Curatione, Libri III (Venice: apud heredes Lucaeantonij Iuntae Florentini, 1546), 29r, 30r, 30v.

16 Athanasius Kircher, Scrutinium physico-medicum contagiosæ Luis, quæ pestis dicitur ... (Rome: Typis Mascardi, 1658), 40.

17 Bernhard Siegert, Passagiere und Papiere: Schreibakte auf der Schwelle zwischen Spanien und Amerika (Munich: Fink, 2006), $119 f$. 
noticed just how much Hegel's attempt to comprehend his time in thought owes to popular publications, especially the journals, of his day. ${ }^{18}$ The notion of "infection," too, can be traced back to common knowledge circulating at the time in the press. D'Hondt refers to a passage from Hegel's writings on the "The Spirit of Christianity" ("Geist des Christentums") written between 1796 and 1800, which refers - completely without any further explanation, as if this were a wellknown story - to the "notorious robbers during the plague at Marseille" ("die berüchtigten Diebe während der Pest zu Marseille”). ${ }^{19}$ D’Hondt's reconstruction makes it plausible that Hegel's knowledge of these thieves probably goes back to a book that had just been translated into German (in 1794) by Baron Knigge, namely Herrn von Antrechaus merkwürdige Nachrichten von der Pest in Toulon, welche im Jahre 1721 daselbst gewüthet hat ("Herr von Antrechau's remarkable news of the plague in Toulon, which raged there in 1721”).

In the book, Jean d'Antrechaus, the town councilor of Toulon at the time of the disaster, gives a detailed report of the epidemic and the measures taken by the authorities to contain it. With utmost meticulousness, he tries to reconstruct the disease's paths of transmission. What deserves particular attention is the narrative he gives of the disease's origin. It is the story of a theft in Marseille:

The plague had manifested itself in Marseille in the hospital when the first bales of merchant goods that had been loaded by Captain Chateau in Syria were opened. They were so poisoned that ... it was considered advisable to drop off part of this cargo on one of the islands near Marseille ... where they were subsequently burned by order of the [royal] court. ...

Some inhabitants of Bandol, a small sea port three miles from Toulon ... landed that night on the island and took a bale of silk with them, which - unopened and not yet spread out - still contained all of the poison. On their return to Bandol, they shared the spoils among themselves. Since they had committed the crime together, each of them now had to bear the punishment, and these miserable ones ... infected their families and the whole village so suddenly that it would not have been possible for any of them to spread the plague any further, almost all of them being infected simultaneously, if a certain barque captain from Toulon named Cancelin, who was in Bandol on that very day, had not had the unfortunate idea of leaving his barque there and returning overland to Toulon. ... In this way, and concealing his absence and how he had traveled, he appeared late in the evening on the fifth of October 1720 before the gate of Toulon, where he was admitted without difficulty under the protection of his proper passport.

18 See Jacques D’Hondt, Verborgene Quellen des Hegelschen Denkens (Berlin: Akademie-Verlag, 1972 [1968]), 157.

19 Georg Wilhelm Friedrich Hegel, "Der Geist des Christentums und sein Schicksal,” in G.W.F.H., Frühe Schriften: Werke, vol. 1 (Frankfurt am Main: Suhrkamp, 1986), 274-418, here 282; “The Spirit of Christianity," in Friedrich Hegel on Christianity: Early Theological Writings, trans. T. M. Knox (New York: Harper \& Bros., 1961), 190. 
Our unlucky hour had come without the inhabitants of Toulon having the slightest inkling of it. ... It was not until two days after Cancelin's return that it became clear he was sick. He died on the eleventh of October and was buried in the usual way for one whose death did not appear strange to anyone. There was not the slightest suspicion of the nature of his illness and of his death until the seventeenth, the day his daughter died. ${ }^{20}$

The report reveals a lively interest in the specific temporality of the epidemic. In periods of plague, time also seems to be seized by a plague; at any rate, Antrechaus cannot avoid the depressing realization that evil is always one decisive step ahead, while knowledge principally comes too late. This not only applies to the interval between infection and the visible outbreak of the disease; this natural delay is compounded by all the temporal shifts resulting from the speed of commerce and the inertia of human behavior, and ultimately also from the dysfunctionalities that must be understood as secondary effects of the plague's sway. Even the city authorities responsible for combating the disease react with a culpable delay; since their fear of isolation motivates them to postpone declaring a state of emergency:

This explanation was sufficient to make the city suspicious; but since no order obligated us to make this declaration ... we let ourselves be moved - by the observation that being abandoned by everyone would be the only fruit we could expect from our frankness ... to wait and see what the consequences would be of the first moment of the plague, and we still hoped to have hampered its course. But what a delusion! and whom did it not mislead!"21

The German translation of Antrechaus's report is accompanied by a detailed foreword written by the Hamburg physician Johann Albert Heinrich Reimarus, which illuminates the medical aspects of the infection of the plague, and which (we can probably say) reflects the most advanced state of epidemiological knowledge at that time. Arguing against the miasma theory, Reimarus takes a position in favor of the new doctrine, according to which "the plague ... does not spread through the air, but only infects by touching contaminated people or things."22 It is thus mainly "coming close ... that must be avoided, and this must be done with utmost care because even the slightest contact with polluted things or people, even if they are still walking about on the streets, can transmit the disease."23

20 Jean d'Antrechaux, Merkwürdige Nachrichten von der Pest in Toulon, welche im Jahr 1721 daselbst gewüthet hat (Hamburg: Bachmann und Gundermann, 1794 [1756]), 32-34.

21 Antrechaux, Merkwürdige Nachrichten, 37.

22 Johann Albert Heinrich Reimarus, "Vorrede: Ueber die allgemeinen Eigenschaften ansteckender Seuchen,” in Antrechaux, Merkwürdige Nachrichten, III-LXXVI, XI.

23 Reimarus, "Vorrede," XII. 
Replacing the atmospheric mythology of the miasma theory, an explanation is now developed here that bases everything on the idea of direct, physical contact, postulating - in search of a medium of transmission - a living vector: because the "pestilent" or "virulent substance" has the special characteristic "that it multiplies in the body of the living animal and passes from one body to the next,"24 it should "be assumed that it must be something living," 25 smaller perhaps even than the "infusion animalcules" ("Infusionsthierchen") ${ }^{26}$ visible under the microscope.

No trace of these subtleties of infection theory can be found in Hegel. On the contrary: he appears to hold fast to the miasma theory, or to mix it with the contagion theory, for example in describing the infection as "diffus[ing] ... like a scent in a compliant atmosphere" ("Verbreiten wie eines Duftes in der widerstandslosen Atmosphäre"). While the medium of transmission is obviously not so important to him, he is all the more interested in the "dynamic scheme" 27 of its progression. He was able to find information about the progression of the disease in Antrechaus, as well as in Reimarus, whose "Preface" also deals with the specific temporality of the epidemic:

The plague lasts a long time everywhere, and the suffering and devastation that it causes during this period is utterly horrible. It is also terrible that its early discovery and infection is hindered by various circumstances, since at first it sneaks around clandestinely, to then spread unstoppably afterwards. ${ }^{28}$

Hence Hegel's infection theory of Enlightenment uses the enlightened epidemiological knowledge of his time, albeit selectively. It is not the paths and substances of transmission that interest him but only infection's temporal logic: the combination of a gradual change taking place unseen with a moment of a delayed comprehension that is then left with no other choice but to subsequently attest the completed change. Hegel was thus able to find a model for his philosophy of consciousness in the plague's mode of transmission, because the belatedness of consciousness is not limited to the particular case of the plague so clearly illuminating its temporal structure. Rather, consciousness (or philosophy, the "owl of Minerva") fundamentally and necessarily comes too late; it always takes place after the fact, as the result of an unconscious process. This is why the metaphor

24 Reimarus, "Vorrede,” XXXIV.

25 Reimarus, "Vorrede," XXXVIII.

26 Reimarus, "Vorrede," XL.

27 D’Hondt, Verborgene Quellen des Hegelschen Denkens, 170.

28 Reimarus, "Vorrede," XVI. 
of infection is so well suited for Hegel's purposes: it perfectly demonstrates what Slavoj Žižek has called the core of Hegel's dialectic: “This is the signifier's performative 'temporal' reach [maille temporelle], which retroactively makes the thing in question ... what it already was." 29

\title{
3 The Patience of Techniques
}

Let us return to Hegel's initial question, namely how the Enlightenment could so easily triumph over traditional faith. With his epidemiological explanation, his description of Enlightenment as infection, Hegel also provides a general hypothesis about the nature of historical change. The essential point is not so much the apparent fractures in which consciousness becomes aware of a change, but rather the long, continuous, invisible movement that precedes them. "Great revolutions which strike the eye at a glance," he explains in the 1790s, "must have been preceded by a still and secret revolution in the spirit of the age, a revolution not visible to every eye, especially imperceptible to contemporaries, and as hard to discern as to describe in words":

\begin{abstract}
Den großen, in die Augen fallenden Revolutionen muß vorher eine stille, geheime Revolution in dem Geiste des Zeitalters vorausgegangen sein, die nicht jedem Auge sichtbar, am wenigsten für die Zeitgenossen beobachtbar und ebenso schwer mit Worten darzustellen als aufzufassen ist. ${ }^{30}$
\end{abstract}

This notion of a subterranean, hidden efficacy corresponds perfectly to the Enlightenment's self-conception, and not only in the secret societies that make a program of imperceptibly conquering the state apparatus. The Enlightenment appreciates artifices and dodges - being, in this regard, merely a faithful imitator of arcane absolutist politics. Paradoxically, even the "public sphere," or the instance opposing the cabals of princely power politics, is conceived of as a countervailing power operating beneath the surface. For example, the philosopher Christian Garve speaks of the widespread "habit of viewing public opinion as an

29 Slavoj Žižek, The Most Sublime Hysteric: Hegel with Lacan (Cambridge: Polity Press, 2014), 24; the original French reads: "Voilà la 'maille temporelle' de la performativité du sifnifiant qui fait de la chose en question ... rétroactivement ce qu'elle était déjà”; Slavoj Žižek, Le plus sublime des hystériques: Hegel avec Lacan (Paris: Presses Universitaires de France, 2011), 49.

30 Georg Wilhelm Friedrich Hegel, "Die Positivität der christlichen Religion (1795/1796), Zusätze,” in Hegel, Frühe Schriften: Werke, vol. 1 (Frankfurt am Main: Suhrkamp, 1986), 190-217, here 203; “The Positivity of Christian Religion," in Hegel on Christianity, 67-181, here 152. 
invisible being of great effectiveness and of counting it among the hidden powers that rule the world." ${ }^{31}$

The space in which Enlightenment spreads is, first of all, a space of discourse: at the beginning of the century, it is a space of learned debate, and later it also becomes a space of popular demands. Accordingly, the infectious or epidemiological character of the Enlightenment comes to attention almost exclusively in the media disseminating this discourse: contemporaries complained about the "flood" of new publications, the rampant "nonsense" of journals, the "plague" of reading societies, the "tempest" of political pamphlets, etc. When Hegel reports on the struggle between Enlightenment and superstition, he too is referring to this world of discourse, the world of public opinion: the undermining of traditional faith and the victory of the Enlightenment takes place upon the field of ideology; it is a "revolution in the spirit of the age."

Of course, the forms of dissemination of the textual universe are particularly suitable for epidemiological interpretation: characters can be repeated and combined at will and are also highly transportable. However, focusing attention on the activity of signs loses sight of another aspect of Enlightenment. In addition to the various forms of discursive dissemination, no less diverse forms of technical modernization can be found. By no means does the infection process of the Enlightenment occur only in the field of discursive debate. It is at least as effective in the field of technical innovation. Precisely if one looks at the pervasiveness of the Enlightenment "in the countryside," one quickly becomes convinced that its actual effectiveness consists not so much in a change of convictions but rather in the slow replacement, repeated again and again in each village, of old technologies by new ones: lightning rods in place of consecrated bells, fire insurance in place of intercessions, smallpox vaccination in place of votive pictures. Like the Christian idol next to the old national idols, technology takes its place as a kind of "new magic" next to traditional magical practices. These continue to exist alongside the new technology for quite some time until, "one fine morning," they are finally knocked off their pedestal.

Hence one can say that the Hegelian model of "patience," or the subliminal change that can be grasped only after the fact, i.e., "too late," corresponds almost exactly to the way in which technical modernization spreads. Technology is not only immediately captivating, its use almost inevitable. Above all, it holds and this is what made it so interesting for the proponents of Enlightenment - the

31 Christian Garve, "Über die öffentliche Meinung," in Garve, Versuche über verschiedene Gegenstände aus der Moral, der Litteratur und dem gesellschaftlichen Leben, vol. 5 (Breslau: Korn, 1802), 291-334, here 294. 
promise of irreversible progress. Once the technologies have become established, once they have become a natural way of acting and interacting, the development becomes impossible to reverse. For example, Diderot sees, "in books, a guarantee for the irreversibility of the Enlightenment - 'les lumières conservées par l'Imprimerie", 32 - and the historian Edward Gibbon is able to dispel the public's fear of a new attack by barbarians. He can do so not only because it is possible to repel invading barbarians with superior war technology, but also because the barbarians would first have to acquire the necessary knowledge in order to resist the technology - meaning they would no longer be barbarians: "before they can conquer, they must cease to be barbarous." 33

In the lee of ideological battles, the technicians get to work executing the details of the Enlightenment. Beyond the area of discursive dissemination that Hegel examines, the epidemiological process of the Enlightenment can be understood as a chain of technical changes - as a process whose effectiveness is only recognized when it is "too late," when the way back is blocked. Hegel's epidemiological model thus contains the possibility, especially when applied to inconspicuous technical processes, of a new understanding of historical change. It is not the prominent events connected to the banner of revolution that matter; rather, what is truly interesting is the cascade of transmission processes that patiently prepares the way for change.

These processes form a kind of "epidemiological strand" of historical observation, the theoretical application of which consists in a systematic devaluation of large fractures and a corresponding, positive revaluation of small, minor actions and inventions. The infamous "great changes" - or what have been bombastically described as an "epistemological caesura” or "historical break," an "epochal threshold" or "revolution" - are (apart from the drama that people make of them) ultimately merely the effects of a quantitative accumulation of anonymous inventions, of small and minute events that relate to previous, minor events and that, in tirelessly repeating themselves, endow these new structures with the status of inescapable evidence or of a "social fact."

One can find this method of observation in Friedrich Nietzsche, in his suspicion of a "barbarous and shameful confusion" 34 that produces the formations

32 Hans Blumenberg, Die Lesbarkeit der Welt (Frankfurt am Main: Suhrkamp, 1989 [1981]), 168. 33 Edward Gibbon, The History of the Decline and Fall of the Roman Empire, vol. 6 (London, Glasgow, and Dublin: printed for Thomas M'Lean [et alii], 1827), 407.

34 Michel Foucault, "Nietzsche, die Genealogie, die Historie," in M.F., Von der Subversion des Wissens (Frankfurt am Main, Berlin, and Vienna: Ullstein, 1982), 83-109, 99; "Nietzsche, Genealogy, History," in M.F., Language, Counter-Memory, Practice: Selected Essays and Interviews, ed. Donald F. Bouchard (Ithaca: Cornell University Press, 1980), 139-164, here 155. 
of culture in the first place; but one finds it above all in the French sociologist Gabriel Tarde, who thinks of the spread of what is new in terms of an epidemiological model, as a process characterized not least of all by a capricious, unpredictable temporality:

A cyclone whirls from neighbourhood to neighbourhood ... An epidemic, on the other hand, rages in a zig-zag line; it may spare one house or village among many, and it strikes down almost simultaneously those which are far apart. An insurrection will spread still more freely from workshop to workshop, or from capital to capital. It may start from a telegraphic announcement, or, at times, the contagion may even come from the past, out of a dead and buried epoch. ${ }^{35}$

Gabriel Tarde's esteem for "small inventions" and their unstoppable spread is echoed in Michel Foucault's micropolitical analyses, in his call to base analysis not on large units but on the "infinitesimal mechanisms, which each have their own history, their own trajectory, their own techniques and tactics" ${ }^{36}$ and also, of course, in the philosophy of Gilles Deleuze, who developed his own model of causality, which we might call "epidemiological": "It is never filiations which are important, but alliances, alloys; these are not successions, lines of descent, but contagions, epidemics, the wind." ${ }^{37}$

\section{Din and Battle Cries}

The idea that what is new spreads subliminally, through an accumulation of hardly noticeable changes, as a gradual infection that can only be perceived after the fact, appears irresistible. Rameau's Nephew emphasizes the advantage of a "politics which moves noiselessly" - or, as Goethe translates, "without din" ("ohne Lerm") - "bloodlessly towards its goal, with no martyrs and not a single tuft of hair pulled out." 38 But the Enlightenment is not content with the mode

35 Gabriel Tarde, The Laws of Imitation (New York: Henry Holt and Company, 1903), 35. The German translation has a slightly different emphasis: "Ein Orkan breitet sich nach und nach aus .... Eine Epidemie wütet anders. Sie schlägt nach links und rechts, verschont dabei dieses oder jenes Haus, die eine oder andere Stadt, erfaßt fast annähernd gleichzeitig viele, weit verstreut liegende Häuser und Städte. Noch freier breitet sich der Aufstand von Stadt zu Stadt, von Fabrik zu Fabrik durch eine Telegraphennachricht aus.” Gabriel Tarde, Die Gesetze der Nachahmung (Frankfurt am Main: Suhrkamp, 2003 [1890]), 59.

36 Michel Foucault, “Two Lectures,” in M.F., Power/Knowledge: Selected Interviews and Other Writings 1972-1977, ed. Colin Gordon (New York: Vintage Books, 1980), 78-108, here 99.

37 Gilles Deleuze and Claire Parnet, Dialogues II (New York: Continuum, 2006 [1977]), 52.

38 Diderot, Rameaus Neffe, 283; Rameau’s Nephew, 101. 
of “extension without opposition" ("gegensatzlose Ausdehnung”), of leisurely spreading.

"[T]his mute weaving of spirit" is, Hegel emphasizes, "only one side of the realization of pure insight" ("Dieses stumme Fortweben des Geistes ... [ist] nur eine Seite der Realisierung der reinen Einsicht”). Its other side consists in reintroducing a moment of conflict and agitation into the process. The Enlightenment becomes spectacular or, in Hegel's words, it makes an entrance as "a noisy ruckus and a violent struggle with its opposite" ("als ein lauter Lärm und gewaltsamer Kampf mit Entgegengesetztem"). ${ }^{39}$ Hegel is referring not only to the events of the French Revolution but also to the earlier skirmishes in the debate about Enlightenment itself. A Jesuit priest no less, yet one who hardly hesitates to throw himself into the battle, complains in 1787 of the escalation of this war, carried out mostly on paper:

Boys in primary schools who have not yet studied philosophy but have read the writings of the Enlighteners ... already strike out like young horses: they taste the war from afar: they prick up their ears, they tremble with desire to fight. ${ }^{40}$

Thus the "mute weaving of the spirit," 41 the creeping, imperceptible change grounded in the patience of officials, teachers, and technocrats, cannot be separated from the noise with which literary and political writers simultaneously stylize the "struggle of the Enlightenment with superstition" as a decisive ideological battle. The din of discourses drowns out the silent proliferation of techniques and technologies; the volume of the public debate contrasts with the secrecy under which the "modernization" of modes of cognition and instruments of political control takes place.

But why is open opposition necessary at all? According to Hegel, it is the fact that the two positions are much too close to each other that is to blame. As stubborn beliefs, faith and pure insight are "both ... essentially the same" ("beide wesentlich dasselbe"), which is why "their giving and receiving is an undisturbed flow of the one into the other" ("ihr Geben und Empfangen ein ungestörtes Ineinanderfließen"). However, it is precisely this proximity that forces an even more intense movement of distancing: in order to allow the difference from the criticized position to become clear, Enlightenment escalates the quarrel, taking pleasure in "thinking of itself as doing battle with something other" ("etwas anderes

39 Hegel, Phänomenologie, 404; Phenomenology, 317.

40 Joseph Anton Weißenbach, anonymously, "Und das heißt nun aufklären: Ein Versuch von einem unbekannten Verfasser," (n.p.: “printed at Ibi - ubi” [“gedruckt zu Ibi - ubi”], 1787), 35.

41 Hegel, Phänomenologie, 404; Phenomenology, 317. 
zu bekämpfen meint”). ${ }^{42}$ Even though this struggle is chimerical because the opponent is no Other, it contributes to the progress of the historical process. It introduces a moment of precipitation or "logical haste" 43 driving the movement of history forward - not only by utopically anticipating what does not yet exist, but also because the din it lets loose returns as a form of reentry into historical process, where it generates evidence of an epochal upheaval, or a so-called revolution in the way of thinking.

The "excess of words," the pathos of the revolution, is thus not only decorative embellishment to a process that takes place anyway in silence, subterraneously. Quite to the contrary, in historical events it takes on the not insignificant function of self-surprise: only the anticipatory theatrical staging of the rupture makes it possible for actors to in fact carry it out. Hence the escalating effect of the din, the inherent dynamics of the political-ideological debate, and the reciprocal goading up of forms of radicalism must also be considered, in addition to the "mute weaving of spirit." 44

Compared to the gradual, subterranean movement of the epidemic spread, this belligerence appears to be a rash movement that gets ahead of itself. The action here seems to come "too early" in a strange way, before the conditions are "ripe” for it. Psychoanalytically speaking, this attitude of rashness or precipitation can be summed up by the concept of hysteria, in contrast to an attitude of cautious waiting, which can be associated with the structure of obsessive-compulsive neurosis. Slavoj Žižek, who follows Jacques Lacan's version of this contradiction, quite obviously sympathizes with the attitude of hysteria, which Žižek attributes equally to Rosa Luxemburg and Hegel, the "most sublime hysteric" ${ }^{45}$ :

The compulsive neurotic hesitates, postpones the act, waits for the right moment and of course never experiences it; but the hysterical woman throws herself "prematurely" into the act in a hurry and thus creates, in [its] failing, the conditions for the right moment of action. ${ }^{46}$

And indeed, if Hegel had been forced to choose between these expressions, he would probably have claimed hysterical precipitation for himself rather than the

42 Hegel, Phänomenologie, 404; Phenomenology, 317.

43 See Jacques Lacan, "Logical Time and the Assertion of Anticipated Certainty: A New Sophism," trans. Bruce Fink and Marc Silver, Published Newsletter of the Freudian Field 2, 2 (1988): 4-22, here 19: "what we are trying to demonstrate: the function of haste in logic."

44 On the dynamic of political radicalization in the French Revolution, see Francois Furet, 1789: Vom Ereignis zum Gegenstand der Geschichtswissenschaft (Frankfurt am Main: Ullstein, 1980 [1978]), 60-61.

45 See Žižek, The Most Sublime Hysteric; Žižek, Le plus sublime des hystériques.

46 Slavoj Žižek, Liebe Dein Symptom wie Dich selbst! Jacques Lacans Psychoanalyse und die Medien (Berlin: Merve, 1991), 13. 
compulsive hesitation. In his writings there are numerous scenes in which the position of cautious waiting, stoic toleration, asceticism hostile to the world, and the passivity of a beautiful soul appear as a disgraceful alternative to militant indignation - from the Jews, who escape Egyptian bondage only because the Egyptians are defeated by the "ten plagues," 47 to the Christians, who believe that "their guilt will be forgiven ... because of the merit of another," 48 to the servant who shuns the fight for life and death, and whose existence will therefore be exhausted in the service of his lord, as "desire held in check" and "vanishing staved off." "49 Accordingly, Hegel is also upset about the dullness of the Germans, who left the Revolution to the French:

Wir Deutschen sind passiv erstens gegen das Bestehende, haben es ertragen; zweitens ist es umgeworfen worden, so sind wir ebenso passiv: durch andere ist es umgeworfen worden, wir haben es uns nehmen lassen, haben es geschehen lassen. ${ }^{50}$

We Germans were passive at first with regard to the existing state of affairs, we endured it; in the second place, when that state of affairs was overthrown, we were just as passive: it was overthrown by the efforts of others, we let it be taken away from us, we suffered it all to happen.

But it would be too easy to see in such statements a fundamental rejection of strategies of waiting, abstention, and evasion. What Hegel calls "science" in the Phenomenology of Spirit has learned from the tricks and dodges of the Jesuits and Enlighteners: it appears not as a "dogmatism of self-assurance" ("versichernder Dogmatismus") but rather as a cunning observing that waits calmly for all discrete, positive determinations to mutually disassemble each other:

[S]o ist sie die List, die, der Tätigkeit sich zu enthalten scheinend, zusieht, wie die Bestimmtheit und ihr konkretes Leben darin eben, daß es seine Selbsterhaltung und besonderes Interesse

47 See Hegel, “Der Geist des Christentums und sein Schicksal," 282: "Die Juden siegen, aber sie haben nicht gekämpft; die Ägypter unterliegen, aber nicht durch ihre Feinde, sie unterliegen, wie Vergiftete oder im Schlaf Ermordete, einem unsichtbaren Angriff”; Hegel, "The Spirit of Christianity," 190: “The Jews vanquish, but they have not battled. The Egyptians are conquered, but not by their enemies; they are conquered (like men murdered in their sleep, or poisoned) by an invisible attack."

48 Georg Wilhelm Friedrich Hegel, "Fragmente über Volksreligion und Christentum," in G.W.F.H., Frühe Schriften: Werke, vol. 1 (Frankfurt am Main: Suhrkamp, 1986), 9-103, here 99; see D’Hondt, Verborgene Quellen des Hegelschen Denkens, 165.

49 Hegel, Phänomenologie, 153; Phenomenology, 115.

50 Georg Wilhelm Friedrich Hegel, Vorlesungen über die Geschichte der Philosophie III: Werke, vol. 20 (Frankfurt am Main: Suhrkamp, 2015), 297; Lectures on the History of Philosophy, vol. 3, trans. E. S. Haldane and Frances H. Simson (London: Routledge, 1955), 391. 
zu treiben vermeint, das Verkehrte, sich selbst auflösendes und zum Momente des Ganzen machendes Tun ist. ${ }^{51}$

In this way, that activity is a kind of cunning which, while seeming to abstain from activity, is looking on to see just how determinateness and its concrete life takes itself to be engaged in its own self-preservation and its own particular interest and how it is actually doing the very opposite.

Even though Hegel repeatedly expresses sympathy for precipitation, his overall philosophical strategy is more in keeping with the attitude of an almost superhuman patience. In the Enzyklopädie der Wissenschaften (Encyclopedia of Sciences), Hegel himself pointed out how closely the idea of a "cunning of reason" ("List der Vernunft") that he formulated is related to the theological idea of divine providence. ${ }^{52}$ But this central figure of Hegelian thought obviously has other sources, which are to be sought less in theological tradition than in the contemporaneous debates about the prevalence of the Enlightenment. The "cunning of reason," one could say, can also be traced back to what might be called the cunning of its techniques, to all of the strategies proven in the "struggle of the Enlightenment with superstition" for realizing the indirect, epidemiological, medial, and technical dissemination of "pure insight."

51 Hegel, Phänomenologie, 53-54; Phenomenology, 34.

52 See Georg Wilhelm Friedrich Hegel, Enzyklopädie der philosophischen Wissenschaften im Grundrisse I: Werke, vol. 8 (Frankfurt am Main: Suhrkamp, 1986), 365, § 209: "Man kann in diesem Sinne sagen, daß die göttliche Vorsehung, der Welt und ihrem Prozeß gegenüber, sich als die absolute List verhält”; Hegel's Logic, Being Part One of the Encyclopaedia of Philosophical Sciences, trans. William Wallace (Oxford: Clarendon Press, 1975), 247: "Divine providence may be said to stand to the world and its process in the capacity of absolute cunning." 